\title{
Introduction to Part I
}

\author{
'A'isha said: I asked the Prophet, \\ 'What person has the greatest claim \\ over a woman?' He said, 'Her husband.' \\ I said, 'What person has the greatest claim \\ over a man?' He said, 'His mother. ${ }^{40}$
}

Classical Islamic law does not grant infertility a particular legal status. ${ }^{41}$ A prepubescent girl, a virgin, a pregnant woman, a breastfeeding woman, and an old woman all have special laws attached to their situation, but neither infertility nor childlessness is a legal category. Nevertheless, in a variety of areas, Islamic law had potentially distinct consequences for medieval infertile women, in part because infertility often correlated with other physical and social conditions, such as irregular menstruation, which in turn had legal implications. These laws did not target infertile women and, indeed, infertility rarely entered into Islamic legal discourse. Each area of the law was its own unit, defined by its own set of scriptural bases (nuṣūṣ) and its own principles (maqāṣid), onto which one can map individual cases. As a result, they are rarely considered together as contiguous topographical features that combine to form a legal landscape which an individual person, such as an infertile woman, might traverse over the course of a lifetime. This section attempts to lay out just such a grand landscape by piecing the discrete units together.

40 Al-Haythamī (d. 807/1405), Majma‘ al-zawā’id (Beirut: Dār al-Kutub al-'Ilmiyya, 2001), 4:405. 41 Only in the modern period are there exceptions. See Aharon Layish, Marriage, Divorce, and Succession in the Druze Family (Leiden: Brill, 1982), 205 and Vardit Rispler-Chaim, "Ḥasan Murād Mannā: Childbearing and the Rights of a Wife,” Islamic Law and Society 2 (1995), 92. The article refers to a fatwā which can be found in Ḥasan Murad Mannā, Fatāwā wa-tawjīhāt (Cairo: Dār alȘafwa, 1990), 201-2.

Ә OpenAccess. (C) 2020 Sara Verskin, published by De Gruyter. (cc))BY-NC-ND This work is licensed under the Creative Commons Attribution-NonCommercial-NoDerivatives 4.0 License. 